\title{
Adherence to HeLa cells, typing by killer toxins and susceptibility to antifungal agents of Candida dubliniensis strains
}

\author{
Adesão a células HeLa, tipagem pelas toxinas \\ "killer" e sensibilidade a antifúngicos de cepas \\ de Candida dubliniensis
}

\begin{abstract}
Gismari Miranda da Silva ${ }^{(a)}$ Fernando Ricardo Xavier da Silveira ${ }^{(b)}$ Maria de Fátima Costa Pires ${ }^{(c)}$
\end{abstract}

(a) MSc Student; (b)PhD, Associate Professor Department of Stomatology, School of Dentistry, University of São Paulo.

(c) PhD, Senior Researcher, Adolfo Lutz Institute, São Paulo.
Corresponding author: Gismari Miranda da Silva Faculdade de Odontologia Depto. de Estomatologia Disciplina de Semiologia Av. Prof. Lineu Prestes, 2227 E-mail: gismari.miranda@uol.com.br
Received for publication on Mar 20, 2006 Sent for alterations on Jul 07, 2006 Accepted for publication on Aug 31, 2006
Abstract: The aim of this study was to evaluate the adherence capability to HeLa cells, the susceptibility to killer toxins and the in vitro susceptibility to antifungal agents (eTest ${ }^{\circledR}$ method - AB Biodisk, Solna, Sweden) of 9 Candida dubliniensis isolates recovered from HIV+ and AIDS patients. The adherence test was strongly positive for strain ATCC 777 and positive for all other strains. Typing by killer toxins revealed two different biotypes among the 9 isolates studied: 888 and 688 . Only biotype 688 (ATCC 777) was susceptible to the $\mathrm{K} 2$ toxin. There was a significant inverse correlation between adherence and killer toxin susceptibility $(\mathrm{r}=-0.8525-\mathrm{p}=0.0035)$. No strains presented resistance to fluconazole, itraconazole, ketoconazole, voriconazole, flucytosine or amphotericin-B. With the exception of ATCC 777, all the other isolates presented similar behavior.

Descriptors: Candida; Cell adhesion; Acquired immunodeficiency syndrome; HIV.

Resumo: O objetivo do presente trabalho foi avaliar o comportamento de cepas de Candida dubliniensis recuperadas de pacientes HIV+ e com AIDS por meio da pesquisa de capacidade de adesão a células HeLa, susceptibilidade a toxinas "Killer" e resistência in vitro a antifúngicos (eTest ${ }^{\circledR} \mathrm{AB}$ Biodisk, Solna, Suécia). O ensaio de adesão foi fortemente aderente para a amostra padrão ATCC 777, e aderente para os demais isolados. Os testes de tipagem das amostras frente às cepas-padrão produtoras de toxinas "Killer" mostraram dois biótipos diferentes dos 9 isolados estudados: 888 e 688 . Somente o biótipo 688 (ATCC 777) de C. dubliniensis foi sensível à toxina K2. Houve correlação inversa significativa entre adesão e sensibilidade a toxinas "killer" $(r=-0,8525-p=0,0035)$. Em relação à pesquisa de resistência a antifúngicos, as amostras de C. dubliniensis foram sensíveis ao fluconazol, itraconazol, cetoconazol, voriconazol, à flucitosina e anfotericina B. Com exceção da amostra ATCC 777, todas as demais mostraram comportamento similar.

Descritores: Candida; Aderência celular; Síndrome de imunodeficiência adquirida; HIV. 


\section{Introduction}

Candida dubliniensis is a newly described species which is closely related phylogenetically to Candida albicans. It was first identified as a new species in 1995, in Dublin, Ireland. ${ }^{19}$

Numerous researches are attempting to identify more detailed characteristics of C. dubliniensis and similitudes and differences between the two related species. ${ }^{4,5,8,9,13,14}$

C. dubliniensis may be isolated from numerous sites but has been frequently isolated from HIV+ patients. ${ }^{5,6,21}$ Notwithstanding the researches studying virulence factors of C. dubliniensis, mainly those isolated from such patients, some properties as adherence and killer toxin resistance have not been well established, opening a perspective to obtain new data to better explain the biological behavior of this new species of Candida.

Adherence to host epithelial cells is the first step in yeast colonization. It occurs due to the ability of the yeast to recognize extra cellular proteins such as laminin, collagen and fibrin, present on the surface of the mucosal host cells. ${ }^{2,5,7,11}$

Killer toxins are low molecular weight glycoproteins produced by 9 Hansenula and Pichia species. They act producing pores on the cytoplasmic membrane, modifying its permeability, resulting in the death of the susceptible yeasts. ${ }^{1,16}$

On the other hand, literature has stressed the importance of some aspects of the resistance of $C$. dubliniensis to the drugs commonly used to treat candidosis, mainly in AIDS patients. ${ }^{3,10,12,17,18}$

The aim of this study was to assess adherence, resistance to killer toxins and susceptibility to antifungal agents of Candida dubliniensis strains isolated from HIV+ and AIDS patients.

\section{Material and Methods}

The Ethical Committee in Research, School of Dentistry, University of São Paulo, approved this investigation (protocol n. 189/03).

Nine strains of Candida dubliniensis were utilized:

- Two isolates (ATCC 777 and ATCC 778 from AIDS patients) furnished by Prof. Claudete R. Paula, from ICB-USP, São Paulo, Brazil.
- Two isolates (CD07 and CD 14 from AIDS patients) furnished by Prof. Arnaldo Colombo, from UNIFESP, São Paulo, Brazil.

- Five strains (013, 038, 058, 096, and 107) were isolated from the oral mucosa of HIV+ patients from the "Casa da AIDS", FM-USP, São Paulo, Brazil.

All the strains were maintained in Sabourauddextrose agar $\left(\right.$ Difco $\left.^{\mathrm{TM}}\right)$ containing Chloranphenicol $(200 \mu \mathrm{g} / \mathrm{ml})$.

All the isolates were re-evaluated according to the identification yeast protocol of the ICB-USP (Mycology section) and the results were confirmed by testing the culture in CHROM-Agar Candida (CHROMagar Company, Paris, France), at $42^{\circ} \mathrm{C}$ in Sabouraud agar. ${ }^{13,14}$

The adherence test was done according to the protocol of the Cell culture section of the Adolfo Lutz Institute ${ }^{15}$ and consisted in obtaining a monolayer of HeLa cells washed in PBS solution $(\mathrm{pH}$ 7.2). A PBS solution ( $\mathrm{pH} 7.2)$ was added to a yeast suspension of 1 to $2 \times 10^{15}$ cells $/ \mathrm{ml}$. Monitoring was performed through a Neubauer Chamber. Each cell culture containing the monolayer of HeLa cells was previously washed in PBS solution ( $\mathrm{pH}$ 7.2). A volume of $2.5 \mathrm{ml}$ of yeast cells was aseptically added to the cell culture and incubated for 1 hour and 30 minutes $\left(37^{\circ} \mathrm{C}\right)$. The plates were fixed in formalin $(5 \%)$ and the cells were dyed by the Gram method. The test was repeated three times.

The following criteria were adopted for cell counting:

- Yeasts with buds smaller than the mother cell were considered as one cell.

- An hyfal cell was considered as one cell.

- Areas with discontinuous monolayer cells were discharged during the count.

The adhered cells count was randomly done in 5 fields of 100 cells for each plate $(100 \mathrm{X})$. To evaluate the results, an arithmetical average of the counts was calculated. The strains which presented an average count of more than 40 cells in $100 \mathrm{HeLa}$ cells were considered strongly adherent. Those which presented an average count between 10 and 40 cells in $100 \mathrm{HeLa}$ cells were considered adherent 
Table 1 - Values $(\mu \mathrm{g} / \mathrm{ml})$ of Sensitivity $(\mathrm{S})$ and Resistance (R) of antifungal drugs.

\begin{tabular}{c|c|c|c|c|c}
\hline Amphotericin & Fluconazole & Fluocytosine & Itraconazole & Ketoconazole & Voriconazole \\
\hline$S<1$ & $S \leq 8$ & $S \leq 4$ & $S \leq 0.125$ & $S \leq 8$ & $S \leq 4$ \\
\hline$R \geq 1$ & $R \geq 64$ & $R \geq 32$ & $R \geq 1$ & $R \geq 32$ & $R \geq 16$ \\
\hline
\end{tabular}

Table 2 - Adherence of the C. dubliniensis isolates to HeLa cells.

\begin{tabular}{l|c|c|c|c|c|c|c|c|c}
\hline \multicolumn{1}{c|}{ Strains } & ATCC777 & ATCC778 & CD 07 & CD14 & 096 & 058 & 107 & 038 & 013 \\
\hline Adherence* Average & 53.53 & 26.93 & 26.53 & 14.13 & 32.27 & 19.20 & 27.93 & 13.93 & 21.20 \\
\hline Standard deviation & \pm 5.15 & \pm 8.25 & \pm 6.46 & \pm 3.87 & \pm 5.65 & \pm 1.55 & \pm 4.30 & \pm 2.54 & \pm 1.44 \\
\hline
\end{tabular}

*Adherence level (average after three counts). Strongly adherent: 40 yeasts in 100 HeLa cells. Adherent: 10 to 40 yeasts in 100 HeLa cells. Weakly adherent: less than 10 yeasts in 100 HeLa cells.

and those with less than 10 cells were considered weakly adherent.

The killer toxins test was done according to Polonelli et al. ${ }^{16}$ (1983), in which the yeasts and the standard cells grow in modified Sabouraud dextrose agar (SDA) (at $25^{\circ} \mathrm{C}$ for 48 hours). The yeasts were suspended in $1 \mathrm{ml}$ of sterile distilled water, to obtain a suspension with a turbidity equivalent to the turbidity of a $0.5 \mathrm{McFarland}$ scale, and mixed in $20 \mathrm{ml}$ of modified SDA containing methylene blue. Then the pattern strains killer producers (K1 to K9 - Parma University) were inoculated onto the agar medium. The cultures with an inhibition zone around the pattern strains were considered susceptible. The triplet codes were mounted according to the sensitivity or resistance of the studied yeast to each killer toxin.

In vitro susceptibility to antifungal drugs was determined by the eTest $^{\circledR}$ method (AB BIODISK, Solna, Uppland, Sweden), using RPMI-1640 Agar (GIBCO $^{\text {TM }}$ - Invitrogen, Carlsbad, Ca, USA) + MOPS (GIBCO ${ }^{\mathrm{TM}}$ - Invitrogen, Carlsbad, Ca, USA). The results were compared to the eTest ${ }^{\circledR}$ Application Sheet (EAS006 AB BIODISK 2005 - 04 M0000145 MF0104) (AB BIODISK, Solna, Uppland, Sweden) for the values of Sensitivity (S) and Resistance (R) (Table 1).

\section{Statistical analysis}

The statistical method employed was Pearson's Correlation (Biostat 3. $0^{\mathrm{TM}}$ ) between the variables adherence and killer toxins (9 pairs; $\mathrm{DF}=7: \mathrm{CI}=95-99 \%$ ).

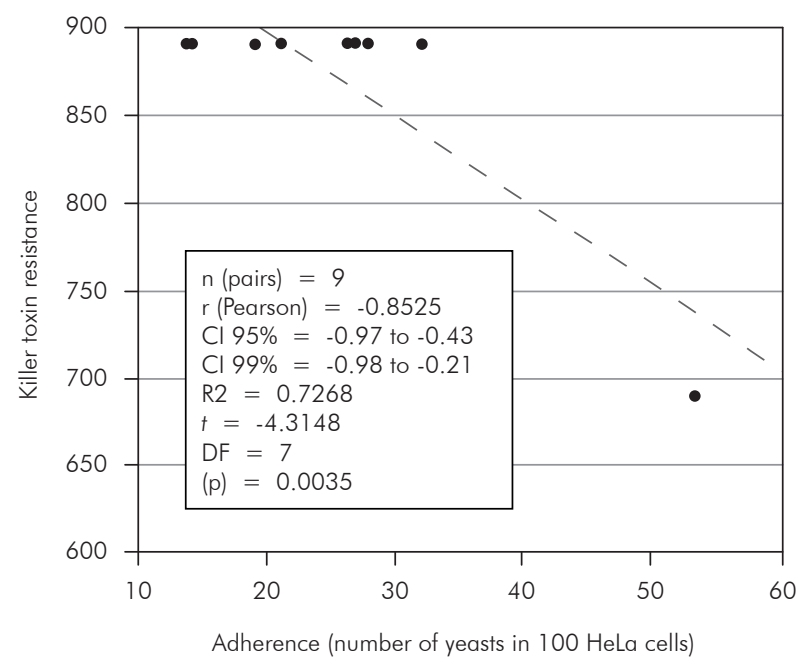

Graph 1 - Pearson's linear correlation for adherence versus killer toxin resistance.

\section{Results}

The adherence results are presented in Table 2.

All the isolates were adherent (ATCC 777 was strongly adherent and all other were adherent).

The killer test revealed two biotypes ( 8 strains of the 888 biotype and 1 strain of the 688 biotype). Strain ATCC 777 was susceptible to the K2 toxin. All the others were resistant to all killer toxins. There was a significant inverse correlation between adherence and killer toxins $(r=-0.8525$ $\mathrm{p}=0.0035)$. This means that for higher adherence values, there were smaller values of resistance to killer toxins (Graph 1).

All isolates were susceptible to the tested antifungal agents and the eTest ${ }^{\circledR}$ results are shown in Table 3. 
Table 3 - eTest results $(\mu \mathrm{g} / \mathrm{ml})$ for the nine C. dubliniensis isolates.

\begin{tabular}{l|c|c|c|c|c|c}
\hline \multicolumn{1}{c|}{ Strains } & Amphotericin & Fluconazole & fluocytosine & Itraconazole & Ketoconazole & Voriconazole \\
\hline CD 07 & $<0.002$ & 0.008 & 0.047 & 0.002 & $<0.002$ & $<0.002$ \\
\hline CD 14 & 0.004 & 0.002 & 0.047 & 0.004 & $<0.002$ & $<0.002$ \\
\hline ATCC 777 & $<0.002$ & $<0.002$ & 0.125 & 0.002 & $<0.002$ & $<0.002$ \\
\hline ATCC 778 & 0.016 & 0.008 & 1.0 & 0.25 & 0.012 & 0.012 \\
\hline 107 & $<0.002$ & $<0.002$ & $<0.002$ & $<0.002$ & $<0.002$ & $<0.002$ \\
\hline 038 & 0.032 & 0.016 & 0.25 & 0.047 & 0.008 & 0.006 \\
\hline 013 & $<0.002$ & 0.003 & 0.125 & 0.003 & $<0.002$ & $<0.002$ \\
\hline 058 & 0.0023 & 0.016 & 0.50 & 0.047 & 0.016 & 0.012 \\
\hline 096 & 0.016 & 0.016 & 0.25 & 0.016 & 0.002 & 0.023 \\
\hline
\end{tabular}

Resistance MIC values: $\geq 1 \mu \mathrm{g} / \mathrm{ml}$ for itraconazole; $\geq 64 \mu \mathrm{g} / \mathrm{ml}$ for fluconazole; $\geq 32 \mu \mathrm{g} / \mathrm{ml}$ for ketoconazole; $\geq 16 \mu \mathrm{g} / \mathrm{ml}$ for Voriconazole; > $1 \mu \mathrm{g} / \mathrm{ml}$ for amphotericin $\mathrm{B} ; \geq 5 \mu \mathrm{g} / \mathrm{ml}$ for Flvocytosine.

\section{Discussion}

We observed that isolate ATCC 777 was strongly adherent and this fact did not occur in relation to all the other isolates which were simply adherent. None of the strains were weakly adherent. Similar results were obtained for C. albicans isolates, ${ }^{15,16}$ but it was not possible to compare them with C. dubliniensis results due to the absence of literature concerning this feature.

In our research we found two killer biotypes: 888 (88.88\%) and 688 (11.11\%). Silva ${ }^{18}$ (1999) found that strains of C. albicans from HIV+ patients were resistant to $\mathrm{K} 2$ and $\mathrm{K} 3$ killer toxins while strains from healthy individuals were susceptible to all the killer toxins. We obtained a different behavior of $C$. dubliniensis when compared to that of C. albicans strains. It is a remarkable fact that our research is the first to correlate adherence and resistance to killer toxins for C. dubliniensis isolates. The comparison was always done in relation to C. albicans strains due to the scarcity of literature results on adherence and killer toxin resistance involving $C$. dubliniensis. We believe that the inverse correlation between adherence and killer toxin susceptibility reached in our results deserves more accurate studies to be confirmed.

The eTest ${ }^{\circledR}$ method was assessed and proved to be an acceptable alternative to the reference methods. All of the isolated strains of C. dubliniensis showed susceptibility to the tested antifungal agents. Our results on resistance to antifungal agents differed from those found in the literature, mainly in respect to itraconazole and fluconazole, which are commonly used drugs for the management of candidosis in AIDS patients. ${ }^{3,10,12,20}$

\section{Conclusions}

1. The ATCC 777 isolate of C. dubliniensis was susceptible to the $\mathrm{K} 2$ toxin. All the other 8 isolates were resistant to all the killer toxins notwithstanding their origin (HIV+ and AIDS patients), configuring a behavioral difference related to HIV+ and AIDS patients, C. albicans carriers.

2. The C. dubliniensis strains tested for antifungal drugs $\left(\mathrm{eTest}^{\circledR}{ }^{ }\right.$) were all susceptible to the azoles, to fluocytosine and to amphotericin B.

3. Except for the pattern isolate ATCC 777, which presented a distinct behavior, all the other C. dubliniensis isolates showed similar behavior.

\section{Acknowledgements}

The authors are indebted to FAPESP (Fundação de Amparo à Pesquisa do Estado de São Paulo) Grant-Process n. 03/10149-0, to Prof. Claudete Rodrigues Paula - ICB USP (C. dubliniensis isolates ATCC 777 and ATCC 778), and to Prof. Arnaldo Colombo- UNIFESP, SP (C. dubliniensis isolates CD07 and CD14). 


\section{References}

1. Bendova O. The killer phenomenon in yeasts. Folia Microbiol. 1986;31(5):422-33.

2. Biasoli MS, Tosello ME, Magaró HM. Adherence of Candida strains isolated from the human gastrointestinal tract. Mycoses. 2002;45(11-12):465-9.

3. Colombo AL, Da Matta D, De Almeida LP, Rosas R. Fluconazole susceptibility of Brazilian Candida isolates assessed by a disk diffusion method. Braz J Infect Dis. 2002;6(3):118-23.

4. Graf B, Trost A, Eucker J, Gobel UB, Adam T. Rapid and simple differentiation of C. dubliniensis from C. albicans. Diagn Microbiol Infect Dis. 2004;48(2):149-51.

5. Hannula J, Saarela M, Dogan B, Paatsama J, Koukila-Kahkola $\mathrm{P}$, Pirinen $\mathrm{S}$ et al. Comparison of virulence factors of oral Candida dubliniensis and Candida albicans isolates in healthy people and patients with chronic candidosis. Oral Microbiol Immunol. 2000;15(4):238-44.

6. Jabra-Rizk MA, Falkler WA Jr, Merz WG, Baqui AA, Kelley JI, Meiller TF. Retrospective identification and characterization of Candida dubliniensis isolates among Candida albicans clinical laboratory isolates from human immunodeficiency virus (HIV)-infected and non-HIV-infected individuals. J Clin Microbiol. 2000;38(6):2423-6.

7. Klotz SA, Rutten MJ, Smith RL, Babcock SR, Cunningham MD. Adherence of Candida albicans to immobilized extracellular matrix proteins is mediated by calcium-dependent surface glycoproteins. Microb Pathog. 1993;14(2):133-47.

8. Mariano P de L, Milan EP, Da Matta DA, Colombo AL. Candida dubliniensis identification in Brazilian yeast stock collection. Mem Inst Oswaldo Cruz. 2003;98(4):533-8.

9. McCullough MJ, Jorge JJ, Lejbkowicz F, Lefler E, Nassar F, Clemons KV et al. Genotypic differences of Candida albicans and C. dubliniensis isolates related to ethnic/racial differences within the same geographic area. Mycopathologia. 2004;158(1):39-41.

10. Moran GP, Sullivan DJ, Henman MC, McCreary CE, Harrington $\mathrm{BJ}$, Shanley DB et al. Antifungal drug susceptibilities of oral Candida dubliniensis isolates from human immunodeficiency virus (HIV)-infected and non-HIV-infected subjects and generation of stable fluconazole-resistant derivates in vitro. Antimicrob Agents Chemother. 1997;41(3):617-23.

11. Ollert MW, Sohnchen R, Korting HC, Ollert U, Brautigam S, Brautigam W. Mechanisms of adherence of Candida albicans to cultured human epidermal keratinocytes. Infect Immun. 1993;61(11):4560-8.

12. Pfaller MA, Messer SA, Gee S, Joly S, Pujol C, Sullivan DJ et al. In vitro susceptibilities of Candida dubliniensis isolates tested against the new triazole and echinocandin antifungal agents. J Clin Microbiol. 1999;37(3):870-2.

13. Pincus DH, Coleman DC, Pruitt WR, Padhye AA, Salkin IF, Geimer M et al. Rapid identification of Candida dubliniensis with commercial yeast identification systems. J Clin Microbiol. 1999;37(11):3533-9.

14. Pinjon E, Sullivan D, Salkin I, Shanley D, Coleman D. Simple, inexpensive, reliable method for differentiation of Candida dubliniensis from Candida albicans. J Clin Microbiol. 1998;36(7):2093-5.

15. Pires MFC, Birman EG, Costa CR, Gambale W, Paula CR. Candida albicans biotypes isolated from the oral cavity of HIV positive patients. Rev Microbiol. 1996;1(27):46-51.

16. Polonelli L, Archibusacci C, Sestito M, Morace G. Killer system: a simple method for differentiating Candida albicans strains. J Clin Microbiol. 1983;17(5):774-80.

17. Ruhnke M, Schmidt-Westhausen A, Morschhauser J. Development of simultaneous resistance to fluconazole in Candida albicans and in Candida dubliniensis in a patient with AIDS. J Antimicrob Chemother. 2000;46(2):291-5.

18. Silva MRR. Variabilidade fenotípica e genotípica de amostras de Candida albicans isoladas da mucosa bucal de pacientes com AIDS [Tese de Doutorado]. São Paulo: Instituto de Ciências Biomédicas da USP; 1999.

19. Sullivan DJ, Westerneng TJ, Haynes KA, Bennett DE, Coleman DC. Candida dubliniensis sp. nov.: phenotypic and molecular characterization of a novel species associated with oral candidosis in HIV-infected individuals. Microbiology. 1995;141:1507-21.

20. Thornsberry C, Sabath LD. Approximate concentration of antimicrobial agents achieved in blood. In: Lenette EH, Balows A, Hauser WJ, Shadomy HJ (eds.). Manual of clinical Microbiology. $4^{\text {th }}$ ed. Washington: American Society for Microbiology; 1985. p. 967-71.

21. Vilela MMS, Kamei K, Sano A, Tanaka R, Uno J, Takahashi I et al. Pathogenicity and virulence of Candida dubliniensis: comparison with C. albicans. Med Mycol. 2002;40:549-57. 